\title{
Association between night shift work, melatonin and estradiol in nurses
}

 \\ From 16th International Charles Heidelberger Symposium on Cancer Research \\ Coimbra, Portugal. 26-28 September 2010
}

Synthesis of melatonin is regulated through visible light exposure, with peak production during the night. Melatonin regulates various physiological processes including secretion of other hormones, and has anticarcinogenic properties as demonstrated in animal and in vitro experiments. It has been suggested that night shift work (exposure to light at night) may disrupt circadian rhythm, and melatonin synthesis leading to other hormonal alterations including increase in estradiol. Few epidemiological studies have investigated an association between night shift work, melatonin secretion and estradiol and their results are inconsistent, with support only from The Nurses Health Study in the US.

In order to clarify the associations between night shift work, melatonin and estradiol we performed analyses of the data collected in the cross-sectional study of 360 nurses working currently on rotating night-shifts and 365 nurses who work currently only during the day. Information on occupational history, use of hormones, menopausal status and breast cancer risk factors was collected in personal interviews. Morning and evening urinary 6-sulfatoxymelatonin (MT6), and estradiol levels in blood were determined.

Preliminary analyses showed no significant associations between current night shift work, melatonin and estradiol in pre-menopausal women. However, significant positive associations were found between total night shift work duration and estradiol in postmenopausal nurses.

Our findings in post-menopausal women support the thesis on alterations in estradiol as a result of prolonged exposure to rotating night shift work in nurses.

\footnotetext{
* Correspondence: bukowska@imp.lodz.pl

${ }^{1}$ Department of Environmental Epidemiology, Nofer Institute of Occupational Medicine, Lodz, Poland

Full list of author information is available at the end of the article
}

\section{Author details}

'Department of Environmental Epidemiology, Nofer Institute of Occupational Medicine, Lodz, Poland. Department of Toxicology and carcinogenesis, Nofer Institute of Occupational Medicine, Lodz, Poland. ${ }^{3}$ National Institute of Occupational Health, Oslo, Norway.

Published: 24 September 2010

\section{doi:}

Cite this article as: Peplonska et al:: Association between night shift work, melatonin and estradiol in nurses. BMC Proceedings 2010 4(Suppl 2):P2.
Submit your next manuscript to BioMed Central and take full advantage of:

- Convenient online submission

- Thorough peer review

- No space constraints or color figure charges

- Immediate publication on acceptance

- Inclusion in PubMed, CAS, Scopus and Google Scholar

- Research which is freely available for redistribution

Submit your manuscript at www.biomedcentral.com/submit
C Biomed Central 